UDC 34

DOI https://doi.org/10.32849/2663-5313/2021.9.15

Tetiana Shumeiko,

PhD in Law, Doctoral Student at the Department of Police Law, National Academy of Internal Affairs, 1, Solomianska square, Kyiv, Ukraine, postal code 03035, TetianaShumeiko@ukr.net ORCID: 0000-0003-0103-300X

Shumeiko, Tetiana (2021). Current regulatory framework for making public policy on firearm circulation in Ukraine. Entrepreneurship, Economy and Law, 9, 102-106, doi: https://doi.org/10.328 49/2663-5313/2021.9.15

\title{
CURRENT REGULATORY FRAMEWORK FOR MAKING PUBLIC POLICY ON FIREARM CIRCULATION IN UKRAINE
}

Abstract. Purpose. The aim of the article is to form a relevant scientific understanding of the current state of affairs in the regulatory framework for making public policy on firearm circulation in Ukraine. Results. The article contributes to forming a relevant scientific understanding of the current state of affairs in the regulatory framework for making public policy on firearm circulation in Ukraine. The author outlines the regulatory framework for making public policy in this field, the system of which is based on the Constitution of Ukraine (paragraph 4 of the preamble, articles 2, 17 and 27) and a set of laws and by-laws of administrative legislation. A critical analysis of the provisions of the legal regulations makes it possible to argue that the current state of the regulatory framework for making public policy on firearm circulation in Ukraine reveals problems, such as the absence of a special law on firearm circulation (although relevant Draft Laws of Ukraine have been continuously submitted to the national parliament since 1998); a complex of provisions of current legislation on firearm circulation in the State reveals the absence of an appropriate mechanism and reliable guarantees for a number of Ukrainian citizens' fundamental rights granted to them by the Constitution of Ukraine (first of all, part 2 of art. 27, and part 1 of art. 92); insufficient quality of the legal regulatory mechanism for public relations in the field of firearm circulation. It is established that the regulatory framework for making public policy on firearm circulation in Ukraine consists of a set of laws and by-laws, which can be grouped into a conditional and complex system of regulations determining the legal regime of firearm circulation in the State. Conclusions. The conclusions to the article summarize the results of the study and emphasise that the solution to most of the problems identified is possible through the creation (taking into account the development of scientific thinking on the substance and content of public policy on firearm circulation) of a special legal regulation on firearm circulation in Ukraine (in which civil circulation of firearms will also be legalized), as well as the arrangement ("codification") of relevant legal regulations.

Key words: public policy on firearm circulation, regulatory framework, regulatory act, firearm circulation, regulatory mechanism, implementation of public policy, reform of legislation, making public policy.

\section{Introduction}

According to national scholars (Barovska 2010; Burbyka 2007), the regulatory framework is a set of legal regulations as well as internal documents that identify the legal status of the object to be legally regulated, determine its content (internal structure), govern its activity (functioning, objectification) and the relations that arise during the functioning (objectification) of this object. Therefore, in the context of making public policy on firearm circulation, the regulatory framework for these public legal processes is a process of law-making (regarding formulation of new provisions, amendments of existing provisions or repeal of existing pro- visions), as well as the results of this law-making activity (in the form of a provision created, a provision amended or a provision repealed), which: 1) make public policy in this field; 2) provide for the rules and standards for the implementation of this policy; 3) implement public policy on firearm circulation. In other words, the legal and regulatory framework for making public policy on firearm circulation in Ukraine is, on the one hand, an individual manifestation of making this public policy, and, on the other hand, a basis for the proper flow of firearms circulation in the State.

However, it should be noted that circulation of weapons is almost the least regulated 
sector of public life in Ukraine, although it is characterized by a multitude of legal regulations which may not compensate the qualitative value by their quantitative value. Nevertheless, the intensive law-making, as well as the large number of scientific studies on the topic, have not produced the expected results for a long time, that is, the quality of the legal and regulatory framework for this important issue remains very low. This proves: 1) the difficulty of providing legal and regulatory support to making public policy on firearm circulation in Ukraine; 2 ) the need for a comprehensive analysis of the current state of affairs in such support, which is complicated by the fact that: to date, the legal and regulatory framework for making public policy on firearm circulation in Ukraine has not yet been the subject of administrative law research.

The regulatory framework for making public policy on firearm circulation in Ukraine has not yet been the subject of a comprehensive study reflecting the actual and current state of affairs in the regulatory framework for making public policy in this field. In addition, many national scientists have already in one way or another studied the legal and regulatory framework for firearm circulation in Ukraine, among them: O.M. Bokii, I.V. Vasyliev, S.V. Didenko, A.V. Korniiets, V.I. Kurylo, S.P. Paranytsia, A.S. Pashyieva, and others. The scientific findings of these scientists may constitute the theoretical basis for a critical analysis of the current state of affairs in the regulatory framework for making public policy on firearm circulation in Ukraine.

Consequently, the aim of this scientific article is to form a relevant scientific understanding of the current state of affairs in the regulatory framework for making public policy on firearm circulation in Ukraine. This aim will be achieved by implementing the following tasks 1) on the basis of a comprehensive analysis of national administrative legislation containing the provisions governing firearm circulation in Ukraine, to outline a system of laws and by-laws that govern making public policy in this field; 2) to highlight the main problems of the current state of affairs in the legal and regulatory framework for making public policy on firearm circulation in Ukraine; 3) to summarize the results of the study in the conclusions to the article.

2. Regulatory framework for the formation and implementation of state policy on arms circulation in Ukraine

A comprehensive analysis of the current legislation in Ukraine permits concluding that the regulatory framework for making public policy on firearm circulation in the country today consists of groups of legal regulations, as follows:

1. Laws and other regulations of the Parliament relating to firearm circulation:

1) The Constitution of Ukraine (paragraph 4 of the preamble, articles 2, 17 and 27);

2) Statutory legal regulations regarding individual issues of firearm circulation, in particular, the Law of Ukraine "On the National Police" (clauses 21 and 22 of part 1, clauses 16 and 17 of part 2 of art. 23 etc.), "On the State Bureau of Investigation" (clause 8 of part 1 of art. 7, para. 1 of part 2 of art. 18), "On the State Service of Special Communication and Information Protection of Ukraine" (part 11 of art. 10, para. 4 of clause 29 of part 1 of art. 14, clause 24 of part 1 of art. 15) and others;

3) Legal regulations and parliamentary resolutions, provisions thereof regulate special issues of firearm circulation, in particular Resolution 2471-XII of the Verkhovna Rada of Ukraine of 17 June 1992 (annexes 1 and 2), Law of Ukraine 3808-XII "On Physical Culture and Sport" of 24 December 1993 (part 1 of art. 1, part 15 of art. 48) etc.;

2. By-laws regulating various aspects of firearm circulation in Ukraine, namely:

1) Issues relating to the operation of the permitting system and the authorization (licence) of objects of the permitting system, as well as to monitoring (supervision) of compliance with the relevant legislation (clauses 2, 4 of Section I, clauses 9 and 11 of Section II of Resolution 576 of the Cabinet of Ministers (hereinafter referred to as the CM) of Ukraine of 12 October 1992; Order 82 of the Ministry of Internal Affairs (hereinafter referred to as the MIA) of 4 February 2019; clause 1 of Order 252 of the Ministry of Health of Ukraine (hereinafter referred to as the MH) of 20 October 1999, clause 8 of Annex 5 of Order 246 of the MH of 21 May 2007);

2) Issues relating to manufacture, repair of firearms and the acquisition, storage, transport and use of firearms, maintenance of shooting ranges, firing fields and stands, in particular these regulations are: a) have general significance (for example, Resolution 1000 of the CM of 2 December 2015, Resolution 1207 of 27 December 2018; Order 622 of the MIA of 21 August 1998); b) cover specific groups of actors that engage in activities that require the acquisition, carrying and use of weapons (departmental weapons), etc. (in particular, Resolution 575 of the CM of 12 October 1992, Resolution 1953 of 25 December 2002; Orders 358 of the MIA of 27 April 2020, 183 of 27 March 2009, 619 of 6 July 2016, 694 of 20 July 2016 (and similar orders, in particular Order 347/631 of the Ministry of Defence of Ukraine and the MIA of Ukraine of 7 July 2016, 
Order 344/1260 of the Department of the State Guard of Ukraine and the MIA of Ukraine of 29 November 2016, Order 1300/366 of the National Anti-Corruption Bureau of Ukraine and the MIA of 16 December 2016, Order 149/358 of the Foreign Intelligence Service of Ukraine and the MIA of Ukraine of 2 May 2018 and a number of other by-laws), 523 of 24 July 1996, 379 restricted of 13 June 2000, Order 86 of the Main Directorate for the Protection of Aquatic Bioresources of the State Committee for Fisheries of Ukraine of 15 June 1998; Order 227 of the Ministry of Education and Science, Youth and Sport of Ukraine of 15 March 2011; Order 343 of the Ministry of Defence (hereinafter referred to as the MD) of Ukraine of 17 July 2018, etc.); c) have statutory and organizational significance (Order 619 of the Administration of the State Special Communication and Information Protection Service (hereinafter referred to as the State Special Communication) of Ukraine of 5 October 2016; Order 650 of the MIA of 28 July 2017, etc.); d) relating to awards in the form of firearms and melee weapon (Order 693 of the MD of 23 October 2012).

A critical analysis of this series and at the many other legal instruments that form the legal and regulatory framework for public policy on firearm circulation enables to conclude regarding the current state of affairs in the legal and regulatory framework for making public policy on firearm circulation in Ukraine that:

1) Currently, no special legislation on firearm circulation exists in Ukraine. It should be noted that the urgent need for a legislative mechanism for the firearms circulation in the State has been recognized as such almost since the proclamation of Ukraine's independence. As a result, on May 13, 1998 Draft Law of Ukraine 1032 "On Arms" was submitted to the National Parliament (on the initiative of the Government) and was withdrawn on December 24, 1999. In the following years, almost two dozen more draft laws were registered in the Ukrainian Parliament, to a greater or lesser extent, aimed at regulating public relations in the field of firearm circulation;

2) The total number of provisions of current legislation on firearm circulation in the State indicates the absence of an appropriate mechanism and reliable guarantees for the exercise by Ukrainian citizens of a number of fundamental rights granted to them by the Constitution of Ukraine. First, with this regard, it is part 2 of article 27 of the Basic Law of Ukraine, which guarantees every citizen the right to protect his or her life and health and the life and health of others from unlawful encroachments. In addition, it should be noted that part 1 of article 92 of the Constitution of Ukraine provides that human and civil rights and freedoms, guarantees of these rights and freedoms and the legal regime governing property, including arms, require to be regulated purely by law;

3) The inadequacy of the legal regulatory mechanism for public relations in the field of firearm circulation, which is a problem, inter alia, due to the fact that:

a) to date, virtually all issues related to firearm circulation have been resolved by by-laws of the MIA of Ukraine (also by joint orders with other central executive authorities) and other departments;

b) a number of legal regulations make legislation scattered, in particular with regard to regulating specificities in the acquisition of non-military firearms, ammunition, knives, pneumatic weapons and other articles and materials, which are subject to the authorization system in the Armed Forces of Ukraine, the Foreign Intelligence Service of Ukraine, the State Border Service of Ukraine and the State Special Communications Service of Ukraine, the State Bureau of Investigation, the Department of the State Guard of Ukraine, the National Anti-Corruption Bureau of Ukraine and some other State bodies. The analysis of the instructions regulating the relevant issues enables to conclude that the provisions of these instructions do not specify the real features of the acquisition of the relevant items of the authorization system in each of these bodies, since in fact, these are documents with common provisions, which differ only in terms of the names of the bodies involved in the acquisition of the items in question. In this context, it would be appropriate to make an instrument (parts of the instrument) that would contain: first, provisions on the acquisition of non-military firearms, their ammunition, which are subject to the authorization system; second, the range of actors to whom the provisions apply. Moreover, when certain features of the acquisition of such items in a given State body require further clarification, they may be further developed in the statutory regulations of these State bodies;

c) a number of by-laws in this field are obsolete and in fact duplicate the provisions of Soviet legislation, which in conjunction with the new legal provisions, lead to contradictory regulations on firearm circulation. This is also manifested in the contradiction between such legislation and the principles of the law relating to firearm circulation in the State (not fully respecting the principle of humanitarianism, justice, equality, etc.);

d) a number of existing regulations on firearm circulation and self-defence equipment 
refer to legislation on firearm circulation, on the certification of the authorisation system objects, etc. that for years (sometimes for decades) have not been in force in Ukraine. For example, the references we have already considered: 1) clause 3 of para. 2 of Regulations approved by Resolution 706 of the CM of Ukraine of 7 September 1993 is no longer in force (since 1 January 2018) under the Decree 46-93 of the CM of Ukraine of 10 May 1993; 2) clause 1 of para. 2 of Order 619 of the MIA of Ukraine of 6 July 2016, sub-clause 2 of clause 1 of Order 694 of the MIA of Ukraine of 20 July 2016, sub-clause 2 of clause 1 of Order 695 of the MIA of Ukraine of 20 July 2016 are not in force (since 11 May 2021), as well as Order 1644 of the MIA of Ukraine of 29 December 2015. Next, in Order 650/272 of the MIA of Ukraine and the State Customs Committee of Ukraine "On approval of the Procedure for the importation from abroad and exportation from Ukraine of special self-defence equipment charged with lacrimal and irritating substances" of 19 October 1993, clause 2 provides for that the relevant authorizations for business entities are issued in consistency with contracts on the supply or sale of self-defence equipment, namely, in accordance with the procedure established by the Instruction approved by Order 164 of the MIA of Ukraine of 25 March 1993, which has not been in force as early as 7 October 1998. Furthermore, sub-clause 1.2 of clause 1 of Order 379 restricted of the MIA of Ukraine of 13 June 2000 states that the legal basis for the use and application of the equipment is the Regulations approved by Resolution 49 of the Council of Ministers of the Ukrainian SSR of 27 February 1991, which has been invalid since 30 December 2017;

r) the absence of a proper legal regulatory mechanism for a large number of issues arising in the field of firearm circulation. Moreover, this conclusion is based not only on contemporary challenges to which this legislation does not effectively respond, but also on established social relations in the field of firearm circula- tion. In particular, there is no State register of arms owners, no official general classification of firearms, and no legal basis for the activities of shooting sports organizations.

\section{Conclusions}

The regulatory framework for making public policy on firearm circulation in Ukraine is a set of laws and by-laws, which may be grouped into a conditional and complex system of regulations determining the legal regime of firearm circulation in the State. Moreover, the complexity of the system of legal regulations considered in this scientific article is excessive and unjustifiable from the perspective of regulatory economy, since it makes the legislation on firearm circulation in Ukraine, which is the framework for making public policy in this field, unclear. This issue is considerably complicated by the fact that the current state of affairs in the legal and regulatory framework for making public policy on firearm circulation in Ukraine is characterized by a variety of problems, specially issues such as: 1) The special law on firearm circulation does not exist; 2) The legislation on firearm circulation does not provide for an appropriate mechanism and reliable guarantees for a number of Ukrainian citizens' fundamental rights, which can be implemented in the field of firearm circulation; 3) The ideological underlay of the legislation on firearm circulation is based on the Soviet concept of regulating social relations in the field of firearm circulation; 4) A number of provisions of the legislation on firearm circulation in Ukraine are obsolete, contradictory and contain references to regulations have not been in force for years (for decades), etc. The solution to most of the problems identified is possible through the creation (taking into account the development of scientific thinking on the substance and content of public policy on firearm circulation) of a special legal regulation on firearm circulation in Ukraine (in which civil circulation of firearms will also be legalized), as well as the arrangement ("codification") of relevant legal regulations.

\section{References:}

Barovska, A.V. (2010). Mekhanizmy realizatsii derzhavnoi informatsiinoi polityky u sferi yevropeiskoi intehratsii [Mechanisms for implementing state information policy in the field of European integration]. Candidate's thesis. Kyiv (in Ukrainian).

Burbyka, M.M. (2007). Robota z personalom v orhanakh prokuratury Ukrainy: orhanizatsiino-pravovi pytannia [Work with staff in the prosecutor's office of Ukraine: organizational and legal issues]. Candidate's thesis. Kharkiv (in Ukrainian). 
Тетяна Шумейко,

кандидат юридичних наук, докторант кафедри поліщейського права, Національна академія внутрішніх справ, площа Солом’янська, 1, Киів, Україна, індекс 03035, TetianaShuтеiko@ukr.net ORCID: orcid.org/0000-0003-0103-300X

\section{АКТУАЛЬНИЙ СТАН НОРМАТИВНО-ПРАВОВОГО ЗАБЕЗПЕЧЕННЯ ФОРМУВАННЯ ТА РЕАЛІЗАЦІЇ ДЕРЖАВНОЇ ПОЛІТИКИ У СФЕРІ ОБІГУ ЗБРОЇ В УКРАЇНI}

Анотація. Метою статті є формування актуальної наукової думки стосовно поточного стану нормативно-правового базису формування й реалізації державної політики у сфері обігу зброї в Україні. Результати. З'ясовано нормативно-правову основу формування та реалізації державної політики у сфері обігу зброї в Україні, систему якої становить Конституція України (зокрема, абз. 4 преамбули, ст. ст. 2, 17 і 27) та сукупність законодавчих і підзаконних актів адміністративного законодавства. На підставі критичного аналізу норм виокремлених нормативно-правових актів обгрунтовується думка про те, що поточний стан нормативно-правового забезпечення формування й реалізації державної політики у сфері обігу зброї в Україні характеризується такими проблемами, як: 1) відсутність спеціального законодавчого акта про обіг зброї (хоча з 1998 р. відповідні проєкти законів України повсякчас подавалися до національного парламенту); 2) загальна сукупність положень чинного законодавства про обіг зброї в державі вказує на відсутність належного механізму та надійних гарантій реалізації громадянами України цілої низки фундаментальних прав, наданих їм Конституцією України (насамперед ч. 2 ст. 27, ч. 1 ст. 92); 3) недостатня якість правового регулювання суспільних відносин у сфері обігу зброї. З'ясовано, що нормативно-правове забезпечення формування й реалізації державної політики у сфері обігу зброї в Україні виявляється в сукупності нормативно-правових актів законодавчого та підзаконного характеру, що можуть бути згруповані в умовну та складну систему актів, які визначають правовий режим обігу зброї в державі. Висновки. Унаслідок проведеного у статті аналізу наголошується на тому, що вирішення більшості з виокремлених проблем можливе шляхом створення (з урахуванням розвитку наукової думки щодо сутності та змісту державної політики у сфері обігу зброї) спеціального законодавчого акта про обіг зброї в Україні, у якому буде легалізовано й цивільний обіг вогнепальної зброї, а також упорядкування («кодифікації») відповідних нормативно-правових актів.

Ключові слова: державна політика у сфері обігу зброї, нормативно-правова основа, нормативно-правовий акт, обіг зброї, правове регулювання, реалізація державної політики, реформа законодавства, формування державної політики.

The article was submitted 15.09.2021

The article was revised 07.10.2021

The article was accepted 28.10.2021 